\title{
BETWEEN THE VISIBLE AND THE INVISIBLE: CALVINO'S CITIES AND MEMORY
}

\section{LUCA POCCI}

\section{Seeing with the Mind's Eye: A Love-Poem to the City}

In his study on the origin and evolution of the city published in 1961, The City in History, Lewis Mumford asked "what is the city? How did it come into existence?... Will the city disappear or will the whole planet turn into a vast urban hive?" (3) An ambitious and erudite work, Mumford's book is a tribute to the city and, specifically, to its major, in fact central role in the history of Western civilization: ${ }^{1}$ the role of setting a scenario for what Aristotle called the pursuit of the good life. While denouncing the alleged crisis of this crucial function, Mumford shows that knowing how cities have been thought and built in the past is an essential aspect of the collective memory of a society: it is a resource that helps plan the urban life and spaces of the future. A decade or so later, in 1972, Calvino published Le città invisibili, a text that aspires to be more than just a Baedeker of fictional urban images. The reasons and questions that inspired the writing of Le città invisibili are similar to the concerns expressed by Mumford at the beginning of his study. In the preface to the 1983 Mondadori edition of $L e$ città invisibili, Calvino reflects on the function(s) we assign to present-day urban spaces and suggests that awareness of the intimate link between the city and the good life risks disappearing from the collective memory of contemporary Western civilization:

Che cosa è oggi la città, per noi? Penso d'aver scritto qualcosa come un ultimo poema d'amore alle città, nel momento in cui diventa sempre più

In effect, The City in History is about a limited area of Western civilization. Mumford himself admits to this in the preface: "As in all my other studies of the city, I have confined myself as far as possible to cities and regions I am acquainted with at first hand, and to data in which I have long been immersed. This has limited me to Western civilization, and even there I have been forced to leave out large significant tracts: namely, Spain and Latin America, Palestine, Eastern Europe, Soviet Russia. I regret these omissions; but since my method demands personal experience and observation, something unreplaceable by books, it would take another liferime to make them good" (xi). 
difficile viverle come città. Forse stiamo avvicinandoci a un momento di crisi della vita urbana, e Le città invisibili sono un sogno che nasce dal cuore delle città invivibili. L'immagine della 'megalopoli,' la città continua, uniforme, che va coprendo il mondo, domina anche il mio libro. Ma libri che profetizzano catastrofi e apocalissi ce ne sono già tanti; scriverne un altro sarebbe pleonastico, e non rientra nel mio temperamento, oltretutto. Quello che sta a cuore al mio Marco Polo è scoprire le ragioni segrete che hanno portato gli uomini a vivere nelle città, ragioni che potranno valere al di là di tutte le crisi. ... Il mio libro s'apre e si chiude su immagini di città felici che continuamente prendono forma e svaniscono, nascoste nelle città infelici.

\section{("Presentazione" ix-x)}

Like Mumford, Calvino believes that the vertiginous rise of the modern megalopolis makes the question "che cosa è oggi la città?" especially cogent. The proliferation of this new urban form is seen as a phenomenon that causes a significant historical turn, a change that cannot but alter the manner(s) in which we think of, and live in the city. The image of an urban monstrum that will grow and expand to the point of coinciding with the whole surface of the world is the ominous future that the authors of The City in History and Le città invisibili envision and fear. This menacing image, however, is an hypothesis, not a prophesy. For both Mumford and Calvino, the advent and rapid development of the modern megalopolis are not the symptoms of an inescapable urbanistic destiny. Rather, they are the signs of a turning point or crisis that reaffirms, in all its urgency, the problem of the historical nexus between the city and the ancient notions of civitas and communitas. ${ }^{2}$

The product of a process of disproportionate urban accretion-a process of quantitative growth rather than qualitative development-the contemporary megalopolis or postmetropolis emerges as an example of anti-city. Mumford and Calvino denounce its rise and diffusion, lucidly perceiving its characteristic and paradoxical dystopian quality. If the urban space has always been, throughout history, the natural setting for the pursuit of the good life, the modern post-metropolis is, in its turn, the dystopi-

${ }^{2}$ In his analysis of the history of ancient megalopolises, Mumford talks about a cycle of growth, expansion, and disintegration. This cyclic pattern would be also applicable to the modern megalopolis. However, Mumford contends that "the cyclic process we are in the midst of is not necessarily a fixed and fatal one. On this fact all wise plans must be based. Our modern world culture, with its ever deepening historic sources and its ever widening contacts, is far richer in still unused potentialities just because it is worldwide, than any other previous civilization" (528). 
an scenario that endangers or, indeed, denies the intimate link between the city and the concept/value of civic community. Mumford goes as far as to contend that the emergence of this sprawling anti-city signals that "man" has come to a dramatic crossroads and must choose

whether he shall devote himself to the development of his own deepest humanity, or whether he shall surrender himself to the now almost automatic forces he himself has set in motion and yield place to his dehumanized alter ego, 'Post-historic Man.' That second choice will bring with it a progressive loss of feeling, emotion, creative audacity, and finally consciousness. (4)

It is safe to remark that Calvino would have never advocated Mum-ford's emphatic tone, let alone his sombre aut aut. The quoted passage is imbued with a humanism that, in addition to sounding generic - with its list of vague, undefined faculties/values that humanity risks losing ("feeling," "emotion," "creative audacity," "consciousness") — is also strongly dogmatic, as the distinction between a fully human 'historic Man' and his "dehumanized alter ego" suggests. A strenuous promoter of precision and exactitude, both in writing and thinking, Calvino always sought to keep away from the generic speculations and categorical claims of ideological diagnoses. However, the fact remains that he shared Mumford's preoccupation with the rise of the modern megalopolis and, as a result, he saw the necessity to reflect upon the meaning of the city and its function at a time of crisis ("Forse stiamo avvicinandoci a un momento di crisi della vita urbana"), a time when urban spaces were becoming less and less livable. This is noteworthy because it proves that Calvino is driven, at least in part, to write Le citta invisibili by the perception of a specific historical problem. Despite its rarefied, quasi oneiric atmosphere, the text is born-again, at least in part - of an experience of personal angst: the anxiety and disorientation provoked by contemporary urban spaces. Le città invisibili, as the author himself put it, is a dream that originates from the heart of the unlivable cities and can be read as one last homage, "un ultimo poema d'amore," to the city.

What does Calvino mean by "ultimo poema d'amore alle città"? The definition evokes a particular literary genre that flourished in the Middle Ages, the laus civitatis. The major exponent of this genre was the Italian poet Bonvesin de la Riva, who wrote a famous panegyric in praise of his city, Milan. ${ }^{3}$ It could be suggested that in defining Le città invisibili as his

${ }^{3}$ Written in 1288 in Latin, De magnalibus Mediolani celebrates the marvels of Milan and the virtues of its citizens. Although at the time it was shaken by intense political struggles, the comune of Milan is presented as a model, a unique 
definitive love poem to the city, Calvino hints at the modes of this medieval literary tradition. However, readers of Calvino's text who activate the literary memory of the laus cannot help but see-and perhaps appreciate-the transformation that the nature of such a genre undergoes in the fictional world of the text. Whereas the authors of the laudes civitatum would commend actual-historical cities, Calvino designs a text that revolves around a collection of fictional urban images. Unlike the Milan praised by Bonvesin de la Riva, Calvino's cities are objects deprived of spatio-temporal existence. More importantly, in addition to being fictional relative to the actual world of their flesh-and-blood creator, the items of this collection enjoy the status of poietic objects also in the world-scenario of the text, where they are presented as figments of Marco Polo's mind. The fifty-five cities are therefore doubly fictional and doubly invisible. Marco Polo has not experienced or discovered them in some remote corner of the world, the fictional world that he inhabits and shares with Kublai Khan. Just like Calvino in the actual world, Marco has visited and seen the cities he describes with his mind's eye. ${ }^{4}$

In light of this, the link between Le citta invisibili and the medieval genre of the laus civitatis would seem to be extremely loose-in fact, almost imperceptible_and, thus, hardly significant. Yet, such a link is more important and notable than might appear, even if it is suggested in an elusive and subtle way. Behind the overall invisible cityscape that Marco Polo proffers to Kublai Khan, there lies the name of a visible city: Venice. In the fictional world constructed by Calvino, Venice maintains one of its historical properties - as Marco Polo's native city - while at the same time, insofar as it is Marco's place of origin, acquiring a special status. Venice is the

civic community. The legacy of the genre of the laus civitatis persists in the humanist age, as it is attested by the fifteenth-century Laudatio Florentine urbis by Leonardo Bruni.

${ }^{4}$ By suggesting that Marco is engaged in a poietic activity, I mean that his activity is a world-creating enterprise. This implies that, within the fictional world of the text, his cities emerge as possible worlds in the basic sense proposed by Saul A. Kripke: "Possible worlds' are stipulated, not discovered by powerful telescopes" (44). Kripke re-elaborates and modifies the traditional Leibnizian conception which "was a metaphysical conception: possible worlds have transcendental existence, they reside in the omniscient divine mind. They are discovered by an exceptional intellect or imagination" (Doležel, 14). In Calvino's text, the creative act of the poietes is characterized by descriptive economy and search for urban essences. The fifty-five sketches of urban scenarios, a collection of miniature possible worlds, reside in the mind of Marco Polo, who imagines and shares them with Kublai Khan. 
indirect source and oblique referent of Marco Polo's imaginary cities. As we will see, the text alludes to the special status of the Serenissima only once. Nevertheless, the reason why it is important to grasp this allusion is that Calvino regarded Venice as a sort of ideal type or model. In a short essay that appeared in 1974 entitled "Venezia: archetipo e utopia della città acquatica," Calvino wrote:

L'epoca in cui viviamo vede tutte le grandi città esistenti in crisi: molte città diventano invivibili; molte città dovranno essere ristrutturate $o$ costruite ex novo secondo piani più conformi al modello veneziano

And he added:

("Venezia" 2691).

Io credo nell'avvenire delle città acquatiche, in un mondo popolato da innumerevoli Venezie... La forza con cui Venezia agisce sulla immaginazione è quella d'un archetipo vivente che si affaccia sull'utopia

("Venezia" 2691-2692).

This declaration of admiration, if not love, for Venice appeared two years after the publication of Le città invisibili. In an assertive and almost visionary tone, Calvino presents Venice as the historical instantiation of his ideal city - the water city ("la città acquatica")—and, thus, as the model and living archetype ("archetipo vivente") for the cities of the future. Quite significantly, Venice functions as a model (prototype) and an archetype also in Le città invisibili; it is the historical city that informs and inspires the fifty-five imaginary cityscapes described by Marco Polo. The power of the image of Venice acts upon Marco's imagination and memory, prompting him to remember his place of origin through a poietic act, namely by projecting or constructing a collection of urban fictions. To the (fictional) artifex of the fifty-five invisible cities, Calvino entrusts a memorial task that assumes an unusual and estranging character: the task of remembering Venice by transmuting its 'real' or 'historical' image into a series of unresembling and unreal cities.

It is important to emphasize though that the nature of Marco's memorial enterprise is, on the whole, less than laudatory. Rather than a collection of ideal descriptions, the overall cityscape that he proposes to the attention of Kublai Khan is an assortment of utopian and dystopian possibilities. By dissolving the image of Venice into a series of urban fictions, Marco sets out to evoke and remember the archetypical native city without however producing an idealizing memory. Thus, if Calvino's text permits us to establish a link between its fictional world and the medieval laus civitatis, it also instructs us to detect the manner in which it deviates from such genre. We could suggest that through the fictional person of Marco 
Polo and his invisible cities, Calvino does not seek to resuscitate and revive a dead genre in an imitative fashion; rather he purports to recover and use it in an idiosyncratic and transformative way. The laus is stripped of its traditional function - the production of a laudatory memory in the discursive form of the panegyric - and simultaneously ascribed a lesser office, that is, the production of a discourse that honours Venice as a source of good and bad memories.

The fact that the quasi laudes that Marco addresses to Venice pay homage to the memory of his city without celebrating or extolling it is an element of major significance. It proves that for the Venetian there are no perfect urban forms. Venice itself is an imperfect model, an archetype that inspires desirable and undesirable visions. To honour the memory of the native city means to evoke and re-imagine, in an oblique and covert fashion, its mundane imperfection. This is confirmed by the nature of the overall cityscape designed by Marco. The collection of urban images that the Venetian describes to Kublai Khan constitutes a variegated utopia and, more precisely, a utopia in the neutral sense of no-place (non-existent place) rather than in the sense of imaginary ideal elsewhere. Consequently, the difference between Marco's cityscape and his native city, within the fictional world of the text, lies essentially in their respective modes of existence. The first stands for the second; it is the imaginary space by which Marco reimagines and remembers a specific spatio-temporal place, his place of origin. On the whole, the fifty-five imaginary cities serve to transmute Venice into an ahistorical place (a no-place), but not to perfect and sublimate it, that is, not to transform it into the best possible City. In other words, while it projects Venice outside of history, this process of transmutation does not save or redeem the Serenissima from its historical imperfection.

We can therefore say that the fictional artifex, Marco Polo, uses the city of Venice as the catalyst ${ }^{5}$ or springboard for his urban visions and as the

${ }^{5}$ Diana Festa McCormick writes that in literary texts "the city often is a catalyst, or a springboard, from which visions emerge that delve into existences unimaginable elsewhere. The city there acts as a force in man's universe; it is a constant element, immutable in its way while constantly renewing itself. It serves as a repository for miseries, hardships, and frustrations, but also for ever-renascent hopes" (15). I have borrowed this idea of the city as a catalyst but I have adapted McCormick's concept to the specificity of the fictional world of Le città invisibili. In Calvino's text, Venice functions as the catalyst/springboard from which visions emerge that explore imaginable or conceivable cities. Moreover, as I have argued, Marco Polo imagines and describes these cities not just for their own sake but also for a memorial purpose. 
covert object of his memorial enterprise. But what is the implication of the dual status that Marco grants to his native city? Or, more aptly put, what kind of memorial task has he been assigned by his creator Calvino? I would suggest that through the fictional person of Marco Polo Calvino experiments with an image of memorial engagement that presents three distinetive attributes: a fully poietic (or creative) character, a dehistoricizing effectiveness and, lastly, an anti-consolatory inclination. The third attribute derives from the nature of Marco's collection of cities, a collection that contains, as I have noted, good and bad, desirable and undesirable (memorial) visions. The first two attributes, instead, are strictly linked and deserve special attention. They emerge in the opening frame of chapter six, in a dialogue between Marco and his only listener/interlocutor, the Tartar emperor:

- Sire, ormai ti ho parlato di tutte le città che conosco. - Ne resta una di cui non parli mai. Marco Polo chinò il capo. - Venezia, - disse il Kan. Marco sorrise. - E di che altro credevi che ti parlassi? L'imperatore non batté ciglio. - Eppure non ti ho mai sentito fare il suo nome. E Polo: - Ogni volta che descrivo una città dico qualcosa di Venezia. Quando ti chiedo di altre città, voglio sentirti dire di quelle. E di Venezia, quando ti chiedo di Venezia. - Per distinguere le qualità delle altre, devo partire da una prima città che resta implicita. Per me è Venezia. Dovresti allora cominciare ogni racconto dei tuoi viaggi dalla partenza, descrivendo Venezia così com’è, tutta quanta senza omettere nulla di ciò che ricordi di lei. (94)

Marco uncovers the dual status of his place of origin by stating that in all he says the native city functions as the presentia in absentia, as the undeclared but constant point of reference for his discourse ("Ogni volta che descrivo una città dico qualcosa di Venezia”). As Kublai Khan's reaction suggests though there seems to be no way to discern or decipher, in the discourse of the Venetian, any allusion to Venice. Without Marco's admission, Kublai Khan would have never made the connection between the descriptions of his messenger and the city of Venice. Yet, the emperor is a lucid, if moody, interlocutor who shows a keen proclivity to follow and, often, dispute the verbal peregrinations of the Venetian. The problem for Kublai Khan is that the object of Marco's memorial enterprise is really unidentifiable and unrecognizable. What Marco's cities say about Venice-in what sense they evoke and remember it-is beyond the emperor's comprehension.

This is hardly the only problem, however. Even after Venice has been overtly named, the Tartar emperor continues to be troubled by the way Marco's memorial engagement works. In a firm and authoritarian tone, he protests against the strategy of his messenger, exhorting him to talk about 
Venice "quando ti chiedo di Venezia" and to describe it "così com'è, tutta quanta senza omettere nulla di ciò che ricordi lei." The message is clear: Venice should be described directly and remembered as it is in its historical form. Kublai Khan expects a discourse that distinguishes Venice from the other cities - the imaginary cities - and which provides an accurate picture of the first, at least according to Marco's experience and memory. This expectation, however, clashes with the unfamiliar, in fact estranging, memorial task that Calvino has assigned to Marco. The Venetian recalls and relives Venice by way of a fully poietic act-namely through the creation of a variegated collection of invisible cities - and in the guise of an evanescent and dehistoricized space. For Marco, Venice counts and must be remembered insofar as it is a living archetype, rather than an historical city. The native city is memorable not for what it is, but for the timeless forms - the fifty-five invisible cities - through which its historical identity can be transfigured and transcended. In Calvino's fictional world, then, memorial work loses its natural and intuitive function. Rather than as an action that aims at re-creating in the present the personal historical experience of a place, it emerges as a dehistoricizing operation and, thus, as an attempt to lift one's gaze above historical time.

\section{A History under Continuous Construction:}

\section{The Cities We Live In and The Cities We Imagine}

And the actual readers? we may ask at this point. What is, for us, the use of the collection of invisible cities and, in general, of the text in which they are included? According to Teresa de Lauretis,

Calvino's is an open text, that is to say a question-producing mechanism, an ambiguous multilevel message that exposes the contradictions internal to its own system and to the cultural codes it assumes rather than a closed text which is an answer-producing mechanism, a device used to resolve contradictions, to pacify the intellect, to reaffirm-however indirectly-the inevitability or cultural patterns, the presumed presence and order of the world. $(17)^{6}$

This question-producing mechanism, though, has a noteworthy ending. It may not be a resolving ending or tight closure, but it is no doubt a

'Similarly, Domenico Scarpa emphasizes the openness of Calvino's text by suggesting that "Le città invisibili sono un libro in forma di domanda, un viaggio alla ricerca di una o più identità: il narratore si allontana da se stesso - così come Marco Polo si è allontanato da Venezia, dal suo primo paesaggio matrice di ogni ulteriore paesaggio" (85). 
highly motivated, and thus significant, close. It should be recalled that in the preface to the Mondadori edition of Le citta invisibili that I have already quoted Calvino himself had observed

un libro (io credo) è qualcosa con un principio e una fine (anche se non è un romanzo in senso stretto), è uno spazio in cui il lettore deve entrare, girare, magari perdersi, ma a un certo punto trovare un'uscita, o magari parecchie uscite

("Presentazione" vi)

In Le città invisibili the ending provides not only the way out of the text, but also the culminating point of the game in which Marco Polo and Kublai Khan have been thus far engaged. In line with the fifty-fifth city (Berenice) envisioned by the Venetian, their final dialogue-in the closing frame of chapter nine-brings into the foreground an ethical perspective. What makes the ending a sort of textual acme is that Marco appears here, more than elsewhere, as the double of the author, the fictional spokesperson for Calvino. Addressing the Tartar emperor, the Venetian suggests that his catalogue/archive of imaginary cities corresponds to the kind of utopia - a discontinuous and powder-fine utopia (utopia pulviscolare) ${ }^{7}$-advocated and sought by his creator:

Se ti dico che la città cui tende il mio viaggio è discontinua nello spazio e nel tempo, ora più rada ora più densa, tu non devi credere che si possa smettere di cercarla. Forse mentre noi parliamo sta affiorando sparsa entro i confini del tuo impero; puoi rintracciarla, ma a quel modo che tho detto (169).

To such an affirmative propensity, Kublai Khan opposes a pessimistic response. In his view, the "utopia pulviscolare" outlined by Marco is, in the final analysis, a futile, self-deceiving project: "—Tutto è inutile, se l'ultimo approdo non può essere che la città infernale ed è là in fondo che, in una spirale sempre più stretta, ci risucchia la corrente." At this point, Marco

${ }^{7}$ The expression utopia pulviscolare appears first in the title of an essay on Charles Fourier ("Per Fourier. Commiato: Lutopia pulviscolare") published in 1973, one year after Le città invisibilit. This essay is part of a series of writings dedicated to the work of the nineteenth-century French utopian writer. The other essays are: "La società amorosa" and "L'ordinatore dei desideri," both published in 1971. In "Per Fourier" Calvino writes: "Comunque, nessuno più pensa di descrivere una città perfetta, né la giornata dei suoi abitanti ora per ora" (308). And once he has rejected the traditional functions of utopian writing, Calvino goes on to suggest his model of utopia, his utopia pulviscolare. "Oggi l'utopia che cerco non è più solida di quanto non sia gassosa: è un'utopia polverizzata, corpuscolare, sospesa” (314). 
concludes the dialogue by rejecting the pessimism of his interlocutor and, more importantly, by inviting him to shift his attention and commitment from the future to the present:

— L'inferno dei viventi non è qualcosa che sarà; se ce n'è uno, è quello che è già qui, l'inferno che abitiamo tutti i giorni, che formiamo stando insieme. Due modi ci sono per non soffrirne. Il primo riesce facile a molti: accettare l'inferno e diventarne parte fino al punto di non vederlo più. Il secondo è rischioso ed esige attenzione e apprendimento continui: cercare e saper riconoscere chi e cosa, in mezzo all'inferno, non è inferno, e farlo durare, e dargli spazio. $(170)^{8}$

This is the epilogue to Le citta invisibili. The fact that it is uttered by Marco seems to confirm that the fictional person of the artifex represents, at least at the close of the text, the point of view of the author. Indeed, one major aspect of the fictional world designed by Calvino is that the reflection about the essence-or 'cityness' - of the city is less an amicable or friendly game than a dispute, a struggle for the last word. By resolving this struggle in favour of Marco, Calvino emphasizes and values, right at the end, the affirmative ethos that the Venetian opposes to the despairing pessimism of Kublai Khan. However, as I have suggested, the ethical core of the epilogue lies in the clear-cut alternative between acquiescing and reacting to the inferno of the visible, in the implicit exhortation to choose the second possibility (the affirmative option), and, above all, in the priority

${ }^{8}$ A similar utopian spirit is found at the end of La giornata d'uno scrutatore (1963). The protagonist, Amerigo Ormea, is a poll watcher at the Cottolengo in Turin, an institution whose function is "dare asilo, tra $\mathrm{i}$ tanti infelici, ai minorati, ai deficienti, ai deformi, giù giù fino alle creature nascoste che non si permette a nessuno di vedere" (7). Even in this citadel of hopeless suffering, reasons Ormea, one can discern glimpses of harmony, momentary and discontinuous signs of the perfect and just City: "La città dell'homo faber, pensò Amerigo, rischia sempre di scambiare le sue istituzioni per il fuoco segreto senza il quale le città non si fondono né le ruote delle macchine vengono messe in moto; e nel difendere le istituzioni, senza accorgersene, può lasciar spegnere il fuoco. S'avvicinò alla finestra. Un poco di tramonto rosseggiava tra gli edifici tristi. Il sole era già andato ma restava un bagliore dietro il profilo dei tetti e degli spigoli, e apriva nei cortili le prospettive di una città mai vista. Donne nane passavano in cortile spingendo una carriola di fascine. Il carico pesava. Venne un'altra, grande come una gigantessa, e lo spinse, quasi di corsa, e rise, e tutte risero. Un'altra, pure grande, venne spazzando, con una scopa di saggina. Una grassa grassa spingeva per le stanghe alte un recipiente-carretto, su ruote di bicicletta, forse per trasportare la minestra. Anche l'uitima citrà dell'imperfezione ha la sua ora perfetta, pensò lo scrutatore, l'ora, l'attimo, in cui in ogni città c'è la Città" (78). 
which is accorded to the temporal frame of the present. This last element is especially important because the present in question is, in effect, also the present of the readers. As Calvino's text progresses toward the conclusion, its link with the actual historical background from which it originates becomes more visible and detectable. The "città continue" and "città nascoste" on which at the end Marco focuses his visionary gaze can be read as allegories of the unlivability and disquiet that plague contemporary real cities. With their puzzling uniformity and uncanny ubiquity, the first call to mind sprawling cities like Los Angeles or disorienting conurbations like Kyoto-Osaka. ${ }^{9}$ Significantly, the opening frame of chapter nine reinforces the link between Marco's "città continue" and the shape, or rather shapelessness, proper to the Californian and Japanese megalopolises.

Il catalogo delle forme è sterminato: finché ogni forma non avrà trovato la sua città, nuove città continueranno a nascere. Dove le forme esauriscono le loro variazioni e si disfano, comincia la fine delle città. Nelle ultime carte dell'atlante si diluivano reticoli senza principio né fine, città a forma di Los Angeles, a forma di Kyoto-Osaka, senza forma (146).

Leonia, Trude, Procopia, Cecilia, and Pentesilea, the 'continuous cities', are there to prove that Le città invisibili is indeed, as Calvino himself defines it, "un sogno che nasce dal cuore delle città invivibili." What is more, they also prove that Calvino's dream is hardly a consolatory or sublimating fantasy. Through their allegorical indirection and vividness, the five "città continue" show how excessive growth and global uniformity undermine the life and livability of contemporary postmetropolises. An analogous absence of sublimating purpose(s) characterizes the visions included in the category of the "città nascoste." Olinda, Raissa, Marozia, Teodora, and Berenice hint at what has become a frequent aspect of modern urban experience: a dismal sense of personal and collective disquiet. However, these visions are on the whole less discomforting and threatening than the ones presented under the label of "città continue." The "città nascoste" remind us that to become engaged in the inferno of the present is not only a possibility, but an ethically desirable option. To do that, one

9 Paola Castellucci contends that some of Marco's most dysphoric visions-Zirma, Isaura, Zenobia, Bauci, Trude-are inspired by the city of New York. Bauci, in particular, would allude to the verticality of New York: "La città sospesa su alti trampoli supera la prospettiva dello sguardo umano: il viaggiatore, dal basso, cerca di individuarla fra le nuvole e non riesce a scorgerla; e gli stessi abitanti possono vedere il terreno su cui si fonda solo con cannocchiali. Bauci non è costruita sul metro della vista umana ma è una città sopra le righe, estrema, a causa della parossistica amplificazione della verticalità" (161). 
must learn to discern who and what, in the midst of the inferno of our anti-cities, are not inferno "e farlo durare e dargli spazio."

We should also note that Calvino invites us to see the nexus between urban form and legibility, suggesting, at the same time, that contemporary continuous cities blur the visibility and importance of that very nexus: given their uniformity and continuity, modern megalopolises are virtually non-legible. In addition to proving that Calvino observed the excessive growth of modern cities with interest and concern, this confirms that Le città invisibili is less detached from its historical time than might appear.

A 'love poem' to the city as a cultural and historical entity, the text alludes to issues of urban planning and experience that were widely debated at the very time it was written. The non-legibility of contemporary urban spaces is one such issue. In The Image of the City, a study published in 1960, Kevin Lynch argued that legibility should be considered a crucial aspect of any cityscape. He described this property as the ease with which the parts of the cityscape "can be recognized and can be organized into a coherent pattern ...so a legible city would be one whose districts or landmarks or pathways are easily identifiable and are easily grouped into an over-all pattern" (3). ${ }^{10}$ Lynch proposed to call the legibility of cities "imageability," emphasizing that the term

does not necessarily connote something fixed, limited, precise, unified, or regularly ordered, although it may sometimes have these qualities. Nor does it mean apparent at a glance, obvious, patent, or plain. The total environment to be patterned is highly complex, while the obvious image is soon boring, and can point to only a few features of the living world. (10)

Contemporary metropolitan spaces lack imageability because, as Lynch noted, "nowhere in the world is there a metropolitan area with any strong visual character, any evident structure. The famous cities all suffer from the same faceless sprawl at the periphery" (94).

Studying the connection between form and legibility (or imageability), Lynch shows that the shapes of many contemporary cityscapes defy our perceptual capacities and, consequently, also our memory. Formlessness and shapelessness are the factors that complicate any attempt to image or remember them.

In the fictional world designed by Calvino, the two protagonists 'solve' this problem by shifting it from the dimension of the visible (which is rep-

${ }^{10}$ Lynch's text studies the look or visual qualities of the American city and "the mental image of that city which is held by its citizens" (2). It focuses, in particular, on three American cityscapes: Boston, Jersey City, and Los Angeles. 
resented by the 'real' cities of Kublai Khan's empire) to the dimension of the invisible (the urban fictions created and described by Marco). Form, legibility (imageability) 11 and memorial content are sought in places that only the mind's eye can see and visit. Such a commitment to the invisible, though, is not a gratuitous escapist move. It is a cognitive escape, a move which enables Marco Polo and Kublai Khan to achieve a special, perhaps superior, vision. The key to understanding what this special vision is can be found in "Visibilità" one of the essays of Lezioni americane. Here Calvino laments that we risk losing an essential faculty that he defines as "il potere di mettere a fuoco visioni a occhi chiusi, di far scaturire colori e forme dall'allineamento di caratteri alfabetici neri su una pagina bianca, di pensare per immagini" (92). ${ }^{12}$ It is precisely this human faculty that inspires and sustains the interaction between the Venetian and the Tartar in Calvino's text. Creating and contemplating invisible cities is a mode of thinking through images. In Marco's case, in particular, the fifty-five urban visions are also a way to visualize, in a circuitous fashion, the memory of Venice, the city of origin. For the Venetian, remembering is a fully creative (poietic) act characterized by an imagistic content. ${ }^{13}$

With his visions Marco transfigures the city of origin, dissolving it, as we have seen, into a collection of estranging images. Venice is recalled by way of a number of oblique reminders that, while lifting it from its historical dimension, transmute it into a composite and timeless (ahistorical) site of memory. However, the ethical appeal that at the end Calvino addresses to the readers serves to (re)introduce and (re)assert the necessity to engage the cities of history, the visible cities. This final move represents an homage

${ }^{11}$ It should not go unnoticed that the legibility of cities is but an aspect of the general legibility of the world. In Calvino, as Mario Porro observes, "La fiducia nella leggibilità del mondo si fonda sulla possibilità di visualizzarlo, di tracciare il grafo del labirinto dei tarocchi, visti dall'alto; l'occhio-mente illumina la carta del mondo" (268).

${ }^{12}$ This confirms that in most of Calvino's texts thought (or thinking) and vision (seeing) are intimately related. For Calvino, "l'atto di vedere non è disgiunto da quello di conoscere: vedere è un atto mentale" (Belpoliti 43).

${ }^{13}$ Mary Warnock points out that the imagist view of memory is both an intuitive and a theoretical notion: "Both common sense and philosophy are inclined to describe the process of recall in terms of images. When people say, 'I can see him now' or 'I can still hear the noise it made,' they mean that they now experience something, as they might say, in their mind's eye or ear. And they might explain what they meant by saying that it was not the original sight or sound they now experienced, but an image of it" (15). 
to the historical significance of the city, a tribute to its role in the evolution of human civilization. The implication seems to be that the city, to put it in Mumford's words, "is the most precious collective invention of civilization ... second only to language itself in the transmission of culture" (53). Ultimately, then, the reflection on the tension between form and formlessness, shape and shapelessness, as well as the search for a just urban model - a legible and livable space-pertain and apply, by necessity, to the cities of, and in, history.

At the same time, though, Calvino also shows-again through the fictional person of Marco Polo-that exploring the dimension of the invisible, namely conceiving and envisioning possible cities, is an essential aspect of such reflection and search. The point of departure is a first, archetypical image "che resta implicita," an image that one can constantly rethink, recreate and remember in different and discontinuous forms. For both Calvino and Marco, the archetypical image is, as we know, the city of Venice. But what about us? What are our urban archetypes? How do we represent to ourselves the cities that we desire and those we fear? The questions that the text invites us to raise suggest that to be citizens in a full sense implies the capacity to operate on two distinct planes. In addition to engaging actively in the life of visible (i.e. real) cities, one should be able to envision, to build in interiore homine, one's own invisible (i.e. possible) cities. This second plane or perspective, the plane of the urban possible, has a major function. It contributes to keep the history of actual cities open and under construction.

\section{The University of Western Ontario}

London, Ontario

\section{Works cited}

Belpoliti, Marco. Locchio di Calvino. Turin: Einaudi, 1996.

Calvino, Italo. La giornata d'uno scrutatore (1963), pp. 3-78 in Romanzi e racconti (Vol. II), eds. Mario Barenghi and Bruno Falcetto. Milan: Mondadori, 1992.

_. Le città invisibili. Turin: Einaudi, 1972.

_. "Per Fourier. Commiato: L'utopia pulviscolare" (1973) pp. 307-314 in

Saggi (Vol. I), ed. Mario Barenghi. Milan: Mondadori, 1995.

—. "Venezia: archetipo e utopia della città acquatica." (1974) pp. 2688-2692

in Saggi (Vol. II), ed. Mario Barenghi. Milan: Mondadori, 1995.

_. "Presentazione" pp. ix-x in Le città invisibili. Milan: Mondadori, 1983.

_. Lezioni americane: sei proposte per il prossimo millennio. Milan: Garzanti, 1988.

Castellucci, Paola. Un modo di stare al mondo: Italo Calvino e l'America. Bari: Adriatica, 1999. 
De Lauretis, Teresa. "Semiotic Models, Invisible Cities." Yale Italian Studies 2.1 (1978): 13-37.

Doležel, Lubomìr. Heterocosmica: Fiction and Possible Worlds. Baltimore: Johns Hopkins University Press, 1998.

Kripke, Saul A. Naming and Necessity. Cambridge, MA: Harvard University Press, 1972.

Lynch, Kevin. The Image of the City. Cambridge, MA: Harvard University Press, 1960 .

McCormick-Festa, Diana. The City as a Catalyst: A Study of Ten Novels. London: Associated University Press, 1979.

Mumford, Lewis. The City in History: Its Origins, Its Transformations, and Its Prospects. New York: Harcourt Brace \& Company, 1961.

Porro, Mario. "Letteratura come filosofia naturale" pp. 253-282 in Riga 9 (Italo Calvino. Enciclopedia: arte, scienza e letteratura), ed. Marco Belpoliti. Milan: Marcos y Marcos, 1995.

Scarpa, Domenico. Italo Calvino. Milan: Bruno Mondatori, 1999.

Warnock, Mary. Memory. London: Faber and Faber, 1987. 